\title{
PENTINGNYA CITRA UNIVERSITAS DALAM MEMILIH STUDI DI PERGURUAN TINGGI
}

\author{
Dedy Ansari Harahap ${ }^{1)}$, Dita Amanah ${ }^{2)}$, Muji Gunarto ${ }^{3)}$, Purwanto4), Khoirul Umam) \\ ${ }^{1)}$ Fakultas Ekonomi dan Bisnis Universitas Islam Bandung, \\ ${ }^{2)}$ Fakultas Ekonomi Universitas Negeri Medan, \\ ${ }^{3)}$ Fakultas Ekonomi dan Bisnis Universitas Bina Darma, Palembang, \\ ${ }^{4)}$ Fakultas Ekonomi dan Bisnis Universitas WR. Supratman, Semarang dan \\ ${ }^{5)}$ Fakultas Ekonomi dan Bisnis Universitas Indraprasta PGRI, Jakarta \\ 1) dedyansari@unisba.ac.id, ${ }^{2)}$ ditamnh@yahoo.com, mgunarto@binadarma.acid, ${ }^{4)}$ cakpo3r@gmail.com, \\ ${ }^{5)}$ khoirul.elmariachi@gmail.com
}

\begin{abstract}
Penelitian ini bertujuan untuk menganalisis pengaruh citra universitas terhadap keputusan mahasiswa memilih studi di Universitas Islam Bandung. Penelitian ini menggunakan pendekatan kuantitatif dengan tipe penelitian eksplanatori. Sampel penelitian berjumlah 388 responden dan diolah secara statistik dengan metode regresi linier sederhana. Hasil penelitian menunjukkan citra universitas berpengaruh terhadap keputusan mahasiswa memilih studi. Temuan tersebut menunjukkan bahwa institusi pendidikan tinggi harus bersaing melalui citra yang dibentuknya. Hal ini terlihat dengan mengukur citra universitas yang dirasakan dan dilihat oleh mahasiswa. Beberapa penelitian menunjukkan bahwa secara umum citra perusahaan penting bagi perusahaan untuk menarik dan mempertahankan pelanggan.
\end{abstract}

Kata kunci : Citra Universitas, Keputusan Mahasiswa, Memilih, Perguruan Tinggi. 


\section{PENDAHULUAN}

Perguruan tinggi pada saat ini sebagai dunia usaha baru yang cukup potensial, bahkan kini reputasi sebuah universitas menjadi sangat penting dan menjadi modal utama bagi para pengembang usaha di bidang pendidikan, citra yang baik mencerminkan kualitas universitas. Tetapi hal ini bukanlah perkara mudah bagi setiap perguruan tinggi mengembangkan institusi perguruan tinggi nya di Indonesia, mengingat semakin ketatnya persaingan dengan perguruan tinggi lain (Harahap, Hurriyati, Gaffar, \& Amanah, 2018).

Tuntutan terhadap perguruan tinggi dewasa ini bukan hanya sebatas kemampuan untuk menghasilkan lulusan berkualitas yang diukur secara akademik, melainkan juga melalui pembuktian akuntabilitas yang baik. Secara umum tuntutan yang diberikan masyarakat kepada perguruan tinggi meliputi jaminana kualitas, pengendalian kualitas dan perbaikan kualitas (BAN-PT, 2008). Perguruan tinggi dapat mencapai tujuan dengan meningkatkan citranya di masyarakat luas, calon mahasiswa dan pihak lainnya melalui peningkatan kinerja perguruan tinggi yang sesuai dengan harapan mahasiswa, sehingga memiliki daya saing tinggi di pasar sasaran.

Keputusan adalah suatu pilihan yang dibuat diantara satu atau lebih alternatif yang tersedia (Harahap \& Amanah, 2018). Keputusan siswa untuk melanjutkan studi mereka di tempat studi yang diinginkan memainkan peran penting untuk kesuksesan masa depan mereka. Jika kenyataan tidak sesuai dengan apa yang diharapkan maka keberhasilan akan berada di bawah ketidakpastian. Tindakan memilih universitas memiliki banyak dimensi dan dampak, yang merupakan bagian dari upaya resolusi serta bagian dari proses pengambilan keputusan. Persaingan yang ketat membuat setiap universitas menyadari kebutuhan untuk sepenuhnya mengeksploitasi asetnya untuk memaksimalkan kinerja dan mengembangkan keunggulan kompetitif (Harahap et al., 2018).

Keputusan mahasiswa untuk melanjutkan studi pada tempat studi yang diinginkan adalah keputusan mahasiswa melakukan pertimbangan-pertimbangan yang disesuaikan dengan keadaan atau kondisi yang ada. Jika keadaan atau kondisi yang terlihat tidak sesuai dengan apa yang diharapkannya, maka akan terjadi keraguan yang dapat berakibat pada keputusan untuk tidak memilih, dalam hal ini keputusan untuk tidak melanjutkan studi di tempat yang diharapkan. Pada kenyataannya pembuatan pilihan memiliki banyak dimensi dan dampak. Memilih merupakan bagian dari suatu upaya pemecahan sekaligus sebagai bagian dari proses pengambilan keputusan (Harahap \& Amanah, 2019).

Persaingan yang meningkat diantara perguruan tinggi menjadikan setiap perguruan tinggi tertantang untuk membentuk citra positif kepada masyarakat. Calon mahasiswa akan memiliki ketertarikan khusus bagi kampus yang memiliki citra positif. Persepsi masyarakat dibentuk oleh citra positif dari suatu universitas sehingga dapat mempengaruhi keputusan calon mahasiswa memilih kampus tertentu untuk melanjutkan studinya. Oleh karena itu citra positif penting untuk diteliti dan selalu dievaluasi oleh setiap universitas.

\section{TINJAUAN PUSTAKA}

\section{Citra Perguruan Tinggi}

Citra kelembagaan digambarkan sebagai kesan keseluruhan yang dibuat di benak masyarakat tentang sebuah organisasi (P. Kotler \& Barich, 1991). Ini terkait dengan berbagai atribut fisik dan perilaku organisasi, seperti nama bisnis, arsitektur, berbagai produk / layanan, tradisi, ideologi, dan kesan kualitas yang dikomunikasikan oleh setiap orang yang berinteraksi dengan klien organisasi.

Dengan demikian, citra institusional memiliki dua komponen utama: fungsional dan emosional (Kennedy, 1977). Komponen fungsional terkait dengan karakteristik nyata yang dapat dengan mudah diukur, sedangkan komponen emosional dikaitkan dengan dimensi psikologis yang dimanifestasikan oleh perasaan dan sikap terhadap suatu organisasi.

Meskipun berbagai proposisi ditemukan dalam literatur tentang bagaimana gambar terbentuk dalam pikiran orang, menurut Macinnis \& Price, (1987) menyatakan bahwa para peneliti di lapangan cenderung setuju bahwa citra kelembagaan adalah hasil dari suatu proses. Proses sensorik ini muncul dari ide, perasaan, dan pengalaman sebelumnya dengan organisasi yang diambil dari memori dan diubah menjadi gambar mental (Yuille \& Catchpole, 1977). Sebagai aturan, orang dihadapkan pada kenyataan yang dibuat oleh 
organisasi dan dapat secara sadar atau tidak sadar memilih fakta yang sesuai dengan konfigurasi sikap dan kepercayaan mereka. Fakta-fakta ini dipertahankan dan kemudian diambil dari memori untuk merekonstruksi gambar ketika organisasi diingat.

Dari beberapa definisi diatas menurut penulis dapat disimpulkan bahwa citra dalam perspektif perguruan tinggi adalah kesan atau pengalaman secara keseluruhan yang dirasakan masyarakat, calon mahasiswa, mahasiswa dan institusi lain terhadap suatu perguruan tinggi. Terkait dengan fasilitas pendidikan, nama baik perguruan tinggi, kualitas pendidikan seperti ; akreditasi perguruan tinggi, fakultas dan program studi yang ada di kampus tersebut.

Dari semua penjelasan dalam latar belakang penelitian ini maka dapat disimpulkan bahwa citra perguruan tinggi menjadi sangat penting sebagai pertimbangan calon mahasiswa dalam menentukan sikap yang tepat untuk memilih melanjutkan studi di perguruan tinggi sesuai kebutuhan dan keinginannya.

\section{Keputusan Mahasiswa Memilih}

Pengambilan keputusan adalah suatu kegiatan individu yang secara langsung terlibat dalam mendapatkan dan mempergunakan barang yang ditawarkan. Keputusan konsumen merupakan salah satu bagian yang terdapat di dalam perilaku konsumen (Kotler, 2008). Menurut Swastha \& Handoko, (2008) mengemukakan bahwa perilaku konsumen merupakan kegiatan-kegiatan individu secara langsung terlibat mendapatkan dan mempergunakan barang dan jasa termasuk dalam proses pengambilan keputusan.

Proses pengambilan keputusan konsumen menurut Kotler, (2008) yaitu : 1). Pengenalan masalah (problem recognition), 2). Pencarian informasi (information search), 3). Evaluasi alternatif (validation of alternativ), 4). Keputusan Pembelian (purchase decision) dan 5). Perilaku pasca pembelian (Post Purchase behavior).

Keputusan pembelian, yang ada dalam penelitian ini adalah keputusan siswa adalah salah satu faktor penting yang perlu dievaluasi oleh setiap perguruan tinggi untuk menarik siswa bunga. Keputusan yang dipilih oleh siswa untuk melanjutkan studi mereka ke perguruan tinggi adalah kunci keberlanjutan siklus kuliah karena siswa adalah aset untuk setiap perguruan tinggi. Keputusan yang diambil adalah individu tindakan dalam memilih perguruan tinggi sebagai tempat belajar itu dijelaskan secara luas dalam perilaku konsumen (Harahap, Hurriyati, Gaffar, Wibowo, \& Amanah, 2017a).

Menurut Harahap, Hurriyati, Gaffar, Wibowo, \& Amanah, (2017b), dari pengertian keputusan pembelian diatas yang diasumsikan sebagai keputusan mahasiswa memilih studi. Dapat dsimpulkan keputusan memilih merupakan sikap calon mahasiswa terhadap suatu universitas untuk menentukan pilihan seseorang terhadap universitas yang dituju. Perilaku mahasiswa memilih studi menentukan suatu universitas yang dipilih untuk mencapai keinginan dan kebutuhan mahasiswa menuntut ilmu yang meliputi ; pengenalan berbagai universitas, pencarian informasi universitas, evaluasi terhadap alternatif memilih universitas, keputusan memilih universitas, dan perilaku setelah memilih universitas.

\section{Penelitian Terdahulu}

Triyaningsih \& Triastity, (2016), dalam penelitiannya yang berjudul "Pengaruh Citra Perguruan Tinggi Terhadap Keputusan Mahasiswa Memilih Perguruan Tinggi dengan Word of mouth Sebagai Variabel Intervening (Survei Pada Mahasiswa Fakultas Ekonomi Unisri Surakarta)" menyatakan ada pengaruh citra perguruan tinggi terhadap keputusan mahasiswa memilih perguruan tinggi. EKSPLORASI Vol. XXIX No.1 - Agustus Tahun 2016.

Agustiani \& Karini, (2017), dalam penelitiannya yang berjudul "Pengaruh Word of Mouth Marketing Terhadap Citra Perguruan Tinggi dan Dampaknya Terhadap Keputusan Menjadi Mahasiswa di STKIP Pasundan Cimahi” menyatakan ada pengaruh citra perguruan tinggi terhadap keputusan mahasiswa memilih perguruan tinggi. Tourism Scientific Journal. Vol. 3 No. 1 Desember Tahun 2018.

Hidayat, Sinuhaji, Widyaningrum, Erdiansyah, \& Adrianto, (2018), dalam penelitiannya yang berjudul "Factors that affect Students Decision to Choose Private Universities in Medan City Indonesia" menyatakan ada pengaruh citra perguruan tinggi terhadap keputusan mahasiswa memilih perguruan tinggi. Academy of Strategic Management Journal Vol. 17 No. 6 Tahun 2018.

Rahman \& Samsul, (2018), dalam penelitiannya yang berjudul "Iklan, Brand Trust dan Brand Image Sebagai Determinan Dalam Memilih Kampus UIN Alauddin Makassar" menyatakan ada pengaruh brand image terhadap keputusan mahasiswa memilih perguruan tinggi. 
ASSETS, Vol.8, No.2, Desember 2018

Amaliya, (2017), dalam penelitiannya yang berjudul "Faktor-Faktor yang Mempengaruhi Keputusan Mahasiswa Memilih Pendidikan Pada Program Studi Pendidikan Ekonomi FE UNY" menyatakan ada pengaruh citra perguruan tinggi terhadap keputusan mahasiswa memilih perguruan tinggi. Jurnal Pendidikan dan Ekonomi, Vol.8, No.1, Tahun 2019

\section{METODE PENELITIAN}

Penelitian ini menggunakan pendekatan kuantitatif dengan metode deskriptif Penelitian ini bertujuan menguji hipotesis, untuk mengetahui pengaruh antar variabel dengan mengacu pada rumusan masalah yang telah ditetapkan serta tujuan penelitian yang diharapkan. Teknik pengambilan sampel dilakukan dengan teknik simple random sampling yaitu diambil secara acak dan memberikan peluang yang sama atau merata pada setiap populasi yang akan dijadikan sampel. Jumlah sampel atau responden yang harus diteliti adalah 383 responden. Data dikumpulkan melalui teknik kuesioner dan teknik analisis data menggunakan pendekatan kuantitatif dengan tipe penelitian explanatory research (penelitian penjelasan) model analisis regresi sederhana. Perhitungan analisis menggunakan program SPSS (Statistical Packages for the Social Science) versi 22.00 Windows.

\section{HASIL DAN PEMBAHASAN}

\section{Hasil}

\section{Analisis Regresi Sederhana}

Model regresi sederhana dengan satu variabel terikat (Y) yaitu keputusan mahasiswa memilih studi dan satu variabel bebas yaitu citra universitas $(\mathrm{X})$ adalah :

$$
Y=0,462+0,828 X_{1}+e
$$

Tabel 1. Regresi Linear Sederhana

\begin{tabular}{lr}
\hline \multirow{2}{*}{ Model } & $\begin{array}{r}\text { Unstandarized } \\
\text { Coefficients }\end{array}$ \\
\cline { 2 - 2 } (Constant) & $\boldsymbol{B}$ \\
Citra Universitas & .462 \\
\hline
\end{tabular}

Sumber: Hasil Olah Data

Dari Tabel 1 menunjukan persamaan regresi $\mathbf{Y}=\mathbf{0 , 4 6 2}+\mathbf{0 , 8 2 8 X}+\mathbf{e}$ menggambarkan bahwa variabel bebas (independen) citra universitas (X) dalam model regresi dapat dinyatakan jika variabel independen berubah sebesar 1 (satu) dan lainnya konstan, maka perubahan variabel terikat (dependen) keputusan mahasiswa memilih (Y) sebesar nilai koefisien $(b)$ dari nilai variabel independen tersebut. Konstanta $(\alpha)$ sebesar 0.462 memberikan pengertian bahwa jika citra universitas $(\mathrm{X})$ tidak mengalami perubahan atau sama dengan nol (0) maka besarnya keputusan mahasiswa memilih (Y) sebesar 0.462 satuan.

Jika nilai $b$ yang merupakan koefisien regresi dari citra universitas (X) sebesar 0.828 yang artinya mempunyai pengaruh positif terhadap variabel dependen (Y) bahwa jika variabel citrai universitas $(\mathrm{X})$ bertambah 1 satuan, maka keputusan mahasiswa memilih (Y) akan mengalami kenaikan sebesar 0.828 satuan dengan asumsi variabel lain tetap atau konstan.

Tabel 2. Uji t

\begin{tabular}{lrr}
\hline \multirow{2}{*}{ Model } & \multicolumn{2}{c}{ Uji t } \\
\cline { 2 - 3 } & t Hitung & t Tabel \\
\hline (Constant) & 3.787 & 1.645 \\
Citra Universitas & 23.660 & 1.645 \\
\hline Sumber: Hasil Olah Data & &
\end{tabular}

Tabel 2 menunjukkan hasil analisis uji parsial (uji t) pada variabel citra universitas (X) diperoleh angka thitung sebesar 23,660 sedangkan angka tabel diperoleh sebesar $=1,645$, karena nilai thitung $>$ tabel, maka Ho1 ditolak dan Ha1 diterima. Hal ini berarti hipotesis diterima yaitu citra universitas positif berpengaruh secara signifikan terhadap keputusan mahasiswa memilih studi.

Tabel 3. Koefisien Determinasi $\left(\mathbf{R}^{2}\right)$

\begin{tabular}{cccr}
\hline Model & R & R Square & $\begin{array}{r}\text { Adjusted } \boldsymbol{R} \\
\text { Square }\end{array}$ \\
\hline 1 & $.769^{\mathrm{a}}$ & .592 & .591 \\
\hline \multicolumn{2}{l}{ Sumber: Hasil Olah Data } \\
\end{tabular}

Tabel 3 menunjukkan bahwa nilai $\mathrm{R}$ yang dihasilkan adalah sebesar 0.769 artinya mempunyai hubungan kuat. Nilai R square $\left(\mathrm{R}^{2}\right)$ adalah 0,592 atau $59,20 \%$ artinya pengaruh variabel bebas citra universitas (X) terhadap variabel terikat keputusan mahasiswa memilih adalah sebesar $59,20 \%$ dan sisanya sebesar $40,80 \%$ di pengaruhi faktor lain.

\section{Pembahasan}

Hasil penelitian yang telah dilakukan pada variabel citra universitas positif berpengaruh secara signifikan terhadap keputusan mahasiswa memilih studi di universitas islam bandung. Hasil ini didukung penelitian yang dilakukan oleh (Agustiani \& Karini, 2017; Amaliya, 2017; Rahman \& Samsul, 2018; Triyaningsih \& Triastity, 2016), menyatakan citra perguruan tinggi memiliki pengaruh terhadap keputusan 
mahasiswa memilih tempat studi.

Hal ini berarti citra yang positif akan membuat masyarakat, calon mahasiswa dan pihak lainnya menyukai suatu perguruan tinggi dikemudian hari, sedangkan bagi perguruan tinggi yang memiliki citra yang baik akan membantu kegiatan institusi dalam bidang pemasaran. Agar citra dapat terbentuk sesuai dengan yang diharapkan oleh perguruan tinggi, maka universitas sebagai penyelenggara pendidikan tinggi harus mampu memahami dan mengeksploitasi unsur-unsur yang membentuk suatu citra sehingga memiliki citra yang baik. Citra yang terbentuk diharapkan dapat menghasilkan sesuatu kualitas yang tinggi atas apa yang diharapkan atau dipersepsikan dengan yang diterima oleh masyarakat, mahasiswa ataupun pihak lain. Hal ini harus didukung oleh kenyataan dan bukti, bukan sekedar pernyataan yang telah dikomunikasikan tanpa adanya bukti nyata.

Hasil penelitian diperoleh nilai $\mathrm{R}^{2}$ sebesar 0,592 yang berarti variabel independen (citra universitas) memberikan pengaruh terhadap variabel dependen (keputusan mahasiswa memilih studi) sebesar 59,20\%, sedangkan sisanya $40,80 \%$ dijelaskan oleh faktor lain diluar dari variabel penelitian ini.

\section{KESIMPULAN DAN SARAN \\ Kesimpulan}

Dari hasil penelitian ini bahwa citra perguruan tinggi mempunyai pengaruh terhadap keputusan mahasiswa memilih studi di perguruan tinggi. Hal ini berarti citra perguruan tinggi menjadi sesuatu hal yang penting bagi calon mahasiswa pada saat memilih studi untuk melanjutkan keperguruan tinggi.

\section{Implikasi}

Citra perguruan tinggi merupakan sebuah kesan yang berada dalam pikiran mahasiswa tentang perguruan tinggi. Hasil penelitian menunjukkan bahwa citra perguruan tinggi mempunyai pengaruh terhadap keputusan mahasiswa memilih studi. Hal ini mengandung implikasi agar kedepannya pimpinan perguruan tinggi untuk lebih memperhatikan citra perguruan tinggi untuk membangun kepercayaan, masyarakat dan calon mahasiswa menentukan pilihannya untuk melanjutkan studi.

\section{Saran}

Penelitian ini telah dilaksanakan sesuai prosedur dan metode penelitian, namun demikian masih memiliki keterbatasan yaitu, faktor yang mempengaruhi keputusan mahasiswa memilih perguruan tinggi dalam penelitian ini hanya terdiri variabel citra perguruan tinggi, sedangkan masih banyak faktor lain yang bisa mempengaruhinya. Selain itu, penelitian ini hanya dilaksanakan di satu lokasi (kampus) yaitu Universitas Islam Bandung, sehingga hasil penelitian ini tidak bisa digeneralisasikan untuk seluruh perguruan tinggi swasta di Indonesia.

\section{REFERENSI}

Agustiani, I. N., \& Karini, R. S. R. A. (2017). PENGARUH WORD OF MOUTH MARKETING TERHADAP THE INFLUENCE OF WORD OF MOUTH MARKETING ON HIGHER EDUCATION IMAGE AND ITS IMPACT ON. Tourism Scientific Journal, 3(1), 32-58.

Amaliya, R. (2017). FAKTOR-FAKTOR YANG MEMPENGARUHI KEPUTUSAN MAHASISWA MEMILIH PENDIDIKAN PADA PROGRAM STUDI PENDIDIKAN EKONOMI FE UNY. Jurnal Pendidikan Dan Ekonomi, 8(1), 34-43.

BAN-PT. (2008). Buku II Standar dan Prosedur Akreditasi Program Studi Sarjana. Jakarta: Kemendikbud.

Harahap, D. A., \& Amanah, D. (2018). Pengantar Manajemen (Kesatu). Bandung: Alfabeta. https://doi.org/10.31227/osf.io/3ub4t

Harahap, D. A., \& Amanah, D. (2019). Assessment in Choosing Higher Education: A Case of Indonesia. Journal of International Business, Economics and Entrepreneurship, 4(1), 10-21.

Harahap, D. A., Hurriyati, R., Gaffar, V., \& Amanah, D. (2018). The impact of word of mouth and university reputation on student decision to study at university. Management Science Letters, 8(6), 649-658. https://doi.org/10.5267/j.msl.2018.4.027

Harahap, D. A., Hurriyati, R., Gaffar, V., Wibowo, L. A., \& Amanah, D. (2017a). Effect of Word of Mouth on Students Decision to Choose Studies in College. 1st International Conference on Islamic Economics, Business, and Philanthropy (ICIEBP 2017) (Vol. 1). Retrieved from http://urn.fi/URN:ISBN:978-952-265-861-6.

Harahap, D. A., Hurriyati, R., Gaffar, V., Wibowo, L. A., \& Amanah, D. (2017b). Pengaruh Reputasi Universitas Terhadap Keputusan Mahasiswa Memilih Studi di Universitas Islam Sumatera Utara. In Prosiding Seminar Nasional \& Konferensi Forum Manajemen Indonesia (FMI 9), Semarang (pp. 1-12). https://doi.org/10.17605/OSF.IO/8ZG6N

Hidayat, R., Sinuhaji, E., Widyaningrum, M., Erdiansyah, \& Adrianto. (2018). Factors that 
affect Students Decision to Choose Private Universities in Medan City Indonesia. Academy of Strategic Management Journal, 17(6), 1-8. Retrieved from https://www.abacademies.org/article s/factors-that-affect-studentsdecision-to-choose-privateuniversities-in-medan-cityindonesia-7749.html

Kennedy, S. H. (1977). Nurturing corporate image. European Journal of Marketing, 11(3), 120-164.

Kotler, P., \& Barich, H. (1991). A Framework for Marketing Image Marketing Image Management. Sloan Management Review, 32(2), 94-104.

Kotler, Philip. (2008). Manajemen Pemasaran (12th ed.). Jakarta: Indeks.

Macinnis, D. J., \& Price, L. L. (1987). The Role of Imagery in Information Processing: Review and Extensions. Journal of Consumer Research, 13(March), 473-491.

Rahman, M. A., \& Samsul. (2018). Iklan, Brand Trust dan Brand Image sebagai Determinan Dalam Memilih Kampus UIN Alauddin Makassar. Assets, 8(2), 188-204.

Swastha, B., \& Handoko, T. H. (2008). Manajemen Pemasaran, Analisa Perilaku Konsumen (Edisi I). Yogyakarta: BPFE.

Triyaningsih, S., \& Triastity, R. (2016).

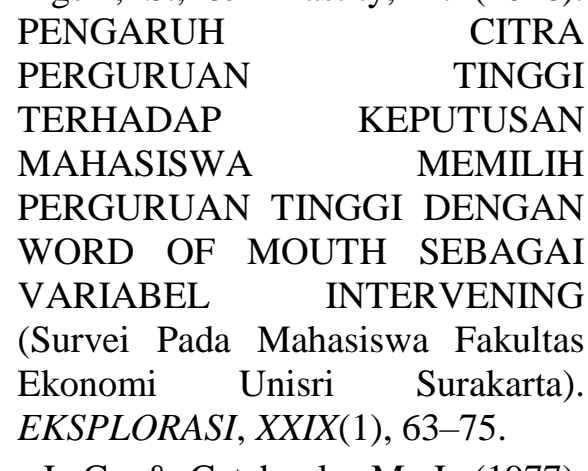

Yuille, J. C., \& Catchpole, M. J. (1977). The role of imagery in models of cognition. Journal of Mental Imagery, 7(1), 171-180.

\{Bibliography\} 